KRZYSZTOF GORLACH

PIOTR NOWAK

MARTA KLEKOTKO

Uniwersytet Jagielloński

Instytut Socjologii

\title{
MYŚL LOKALNIE, DZIAEAJ GLOBALNIE: CZYLI O PEWNYM ROZUMIENIU ROZWOJU SPOŁECZNEGO W DOBIE GLOBALIZACJI
}

\section{Uwagi wstępne}

-ytuł niniejszego opracowania został sformułowany nieco przewrotnie. Na pierwszy rzut oka jego pierwsza część może też sugerować pomyłkę w przytoczeniu znanego hasła, używanego najczęściej przez ekologów, a mającego stanowić odzwierciedlenie istoty i logiki funkcjonowania zglobalizowanego świata. Jak stwierdza np. w swoim szkicu Julian Amey z Uniwersytetu Warwick w Wielkiej Brytanii:

\begin{abstract}
Stwierdzenie „myśl globalnie, działaj lokalnie” po raz pierwszy zostało użyte w kontekście wyzwań związanych z ochroną środowiska. Jest bowiem bardziej efektywnym rozwiązaniem dla jednostki ograniczenie ilości konsumowanej przez nią energii, aniżeli oczekiwanie na jakieś działanie w skali globalnej. Co jednak oznacza to twierdzenie w kontekście biznesu? Wielkie firmy takie, jak: McDonalds czy Honda odnoszą sukcesy w skali globalnej, ale ich produkty są przykrojone do wymogów poszczególnych krajów ${ }^{1}$.
\end{abstract}

W swoim szkicu autor twierdzi dalej, że kluczem do rozważenia tej sytuacji nie jest tylko owa fraza „myśl globalnie, działaj lokalnie”, ale też „dziel się wiedzą i bądź uczestnikiem sieci". Hasło to zatem - jak można w pewnym uproszczeniu stwierdzić - oznacza tyle, że aby cokolwiek w sposób rzeczywisty dokonać w określonym miejscu, społeczności, których synonimem jest

\footnotetext{
${ }^{1}$ Por. www2.warwick.ac.uk/ knowledge/business/thinklocal/(dostęp: 26.05.2013)
} 
owa lokalność, należy wszelkie podejmowane kwestie traktować z odniesieniem globalnym, jako konkretne sposoby przejawiania się bardziej ogólnych problemów, właściwych wielu społeczeństwom rozrzuconym po całym świecie.

Zwróćmy jednak uwagę, że przywołane przez Amey`a przykłady dotyczą przede wszystkim kwestii wchodzenia wielkich ponadnarodowych korporacji na lokalnie rynki. Działanie lokalne oznacza po prostu sprzedawanie swoich "globalnych” towarów w „opakowaniach”, które mogą trafiać niejako w gust czy potrzeby ukształtowanych w lokalnych kontekstach i tradycjach konsumentów. W przywołanym z kolei przykładzie z zakresu ekologii chodzi po prostu o to, że oczekuje się od lokalnych społeczności rezygnacji z zaspakajania swoich potrzeb bez jakichkolwiek gwarancji podjęcia określonych działań na szczeblu globalnym. Nic dziwnego, że przesłanie rozumowania Amey`a zostało poddane przez jego oponentów² ostrej krytyce, jako ilustracja raczej innej tezy, którą można byłoby sformułować w postaci stwierdzenia: „myśl globalnie i działaj globalnie”. W zglobalizowanym świecie zatem kwestia lokalności - ich zdaniem - została wymazana w sposób całkowity.

W tym opracowaniu chcielibyśmy w związku z tym poddać szerszej refleksji problem relacji między tym co lokalne, a tym co globalne właśnie w kontekście wspomnianego na wstępie stwierdzenia. Naszym zdaniem stwierdzenie „myśl globalnie, działaj lokalnie” w gruncie rzeczy zawiera ukryte założenie o dominacji tego co globalne nad tym co lokalne. To co lokalne jawi się zatem jako wdrożenie pewnego globalnego projektu, co najwyżej w jakiś sposób przykrojonego do potrzeb lokalnych, choć - jak twierdzą krytycy - w dość wątpliwy, jeśli w ogóle, sposób. Zgadzamy się z tą krytyką. Jednak w naszych rozważaniach chcielibyśmy pójść o krok dalej. Chcielibyśmy zaproponować odmienny sposób rozumowania, którego przesłanie brzmiałoby: „myśl lokalnie, działaj globalnie”. Uzasadnienie takiego przesłania wymaga jednak poddania refleksji nie prostych relacji tego co lokalne z tym co globalne, ale bardziej złożonego mechanizmu rozwojowego, stanowiącego istotę społeczeństwa zglobalizowanego. Z kolei, aby dobrze przedstawić istotę tego mechanizmu, konieczna jest refleksja na temat nowych ujęć tego co lokalne w społeczeństwie poddanym procesom globalizacji. 0 tym wszystkim staramy się opowiedzieć w tym krótkim opracowaniu.

2 Tamże. 


\section{O lokalności, miejscu i glokalności}

Jednym z wyróżników współczesnej socjologii jest zdecydowana niechęć do używania tradycyjnych pojęć i zastępowanie ich rozmaitymi neologizmami. Nie miejsce tu oczywiście na jakąś ogólniejszą i bardziej pogłębioną refleksję na ten temat. Można - w naszym przekonaniu - co najwyżej stwierdzić, że jest to pochodną nie tylko - jeśli można to tak określić - przełomu postmodernistycznego, który także dotknął nauki społeczne, ale również - wskazując na bardziej konkretne czynniki - efektem zwrotu kulturowego (zwracającego uwagę na wyobrażeniowy przede wszystkim charakter rzeczywistości społecznej), idei poststrukturalizmu (skupiających uwagę na elastycznym i płynnym charakterze rzeczywistości społecznej), wreszcie także zapożyczeń z innych dyscyplin (niekoniecznie z obszaru nauk społecznych), będących swoistym przejawem wychodzenia poza granice określonych i tradycyjnie zdefiniowanych dyscyplin naukowych ${ }^{3}$. W tym kontekście warto więc wskazać, że taka sytuacja odnosi się także do rozważań poświęconych w socjologii problematyce miejsca. Trudno pewnie byłoby dowieść, że koncepcja miejsca wyparła z rozważań socjologów wsi koncepcję społeczności lokalnej. Jednak twierdzenie minimalistyczne, wskazujące na dostrzegalne pojawienie się tej pierwszej koncepcji w rozważaniach socjologów (także wsi) jest z pewnością do utrzymania. Spróbujmy zatem przyjrzeć się kilku wybranym typom refleksji na temat miejsca, traktując je jednocześnie (tak jak i tradycyjnie rozumianą społeczność lokalną) jako obszar podejmowania określonych działań w skali „lokalnej”. Stanowi to pierwszy element w naszym rozumowaniu, dotyczącym wspomnianej we wstępie zasady: „myśl lokalnie, działaj globalnie”.

Tradycyjne ujęcia społeczności lokalnych przyjmują perspektywę określonych zespołów ludzkich jako podmiotów osadzonych (settled) w ramach określonych fragmentów przestrzeni. Stąd właśnie bierze się ten sposób myślenia, który wskazuje na powiązanie takich społeczności z konkretnymi fragmentami tej przestrzeni, czyli właśnie z „miejscami”. W koncepcjach ukazujących tradycyjną wieś czy społeczności miejskie, owo „miejsce” staje się niejako matecznikiem określonej społeczności, a jego granice

${ }^{3}$ Por. szerzej m.in. na ten temat: P. Sztompka, Współczesna socjologia wśród innych nauk społecznych: burzenie murów i przekraczanie granic, [w:] Władza, naród, tożsamość. Studia dedykowane Profesorowi Hieronimowi Kubiakowi, pod. red. K. Gorlacha, M. Niezgody, Z. Seręgi, Wydawnictwo Uniwersytetu Jagiellońskiego, Kraków 2004, s. 39-44. 
tworzą jednocześnie granice „swojego” świata, jakże innego od tego wszystkiego, co jest ulokowane „na zewnątrz” i zasiedlone przez „obcych”. Już jednak procesy modernizacji dokonują swoistego rozluźnienia relacji pomiędzy mieszkańcami (społecznością) a ich „miejscem”4. Dalsze wzmocnienie tej tendencji przynoszą procesy globalizacyjne, które choć prowadzą do dalszego rozluźnienia wspomnianych relacji, niekoniecznie jednak pomniejszają rolę rozmaitych wartości, związanych z charakterystykami poszczególnych „miejsc”. Wspomniane rozluźnienie powoduje jednak to, że owe wartości i sposób przypisania ich do określonych fragmentów przestrzeni zwanych „miejscami”, staje się przedmiotem refleksji, kontrowersji czy negocjacji pomiędzy różnymi aktorami, dla których w dalszym ciągu posiadają one określone znaczenie. W ten sposób określone fragmenty przestrzeni geograficznej zostają poddane daleko bardziej intensywnej i różnorodnej konstrukcji społecznej, aniżeli można to było zaobserwować w okresie społeczeństwa tradycyjnego czy też nawet już podlegającego procesom modernizacji. Ta charakterystyka zawarta w koncepcji miejsca, staje się jego zdecydowanym wyróżnikiem ${ }^{5}$.

Takie ujęcie miejsca daje podstawy do wprowadzenia bardziej złożonych jego koncepcji. I tak np. Harvey C. Perkins proponuje przede wszystkim w odniesieniu do miejsc ulokowanych na obszarach (przestrzeniach) wiejskich trojakiego rodzaju perspektywę $e^{6}$. Z jednej strony jest to ujmowanie miejsca w perspektywie utowarowienia ${ }^{7}$, polegającego na tym, że „miejsca wiejskie” są obecnie nie tylko fragmentami przestrzeni, gdzie odbywa się produkcja artykułów żywnościowych (czy może-lepiej powiedzmy-surowców do produkcji artykułów spożywczych), ale także swoista konsumpcja takich „artykułów”, jak krajobraz naturalny czy też kulturowy wsi. Drugi wymiar wyznacza zróżnicowanie owego utowarowienia z uwagi na to, że

${ }^{4}$ Por. szerzej na ten temat np. K. Gorlach, Socjologia polska wobec kwestii chłopskiej, Universitas, Kraków 1990 oraz tegoż, Socjologia obszarów wiejskich. Problemy i perspektywy, Wydawnictwo Naukowe SCHOLAR, Warszawa 2004.

${ }^{5}$ A. Wyborg, Place, nature and migration: student attachment to their home places, "Sociologia Ruralis" 2004, z. 4 (44), s. 417-418.

${ }^{6}$ H. C. Perkins, Commodification: re-resourcing rural areas, [w:] Handbook of Rural Studies, pod red. P. Cloke, T. Marsden, P. H. Mooney, Sage Publications, London-Thousand Oaks-New Delhi 2006, s. 243-257.

7 Na procesy utowarowienia zwraca także uwagę: J. Pakulski, Postmoderm social theory, [w:] New Blackwell Companion to Social Theory, pod red. B. S. Turner, Wiley-Blackwell, Malden-Oxford-Chichester 2009, s. 251-280. 
samo ono jest procesem kontrowersji i negocjacji między różnymi aktorami, uwzględniającymi różne wymogi i charakterystyki określonych „miejsc”. Wszystko to pociąga za sobą wyróżnioną przez Perkinsa trzecią perspektywę, odnosząca się do badaczy, którzy obecnie w większym aniżeli uprzednio stopniu muszą skupiać się na procesach konstrukcji czy też ciągłej rekonstrukcji społecznej określonych miejsc, analizując jednocześnie charakter relacji pomiędzy aktorami uczestniczącymi w tych procesach.

Inni autorzy do takiego sposobu rozumowania dorzucają nowe elementy. Rozważanie wpływu utowarowienia i relacji rynkowych uzupełnione zostaje np. o problematykę obywatelskiej i politycznej mobilizacji ${ }^{8}$. W tej perspektywie zwraca się uwagę na rozmaite lokalne, ale i - co niezwykle ważne - ponadlokalne czynniki odgrywające rolę w tworzeniu rozmaitych sposobów rozumienia oraz tożsamości, związanych z określonymi „miejscami”. W tym samym nurcie można także umieścić rozważania polskich autorów ${ }^{9}$, rozwijających koncepcję „społecznego tworzenia miejsc”. Koncepcja ta w sposób wyraźny nawiązująca do Bergera i Luckmana idei „społecznego tworzenia rzeczywistości”10 , zawiera kilka istotnych twierdzeń. Przede wszystkim wskazują one na miejsce jako ten fragment przestrzeni, który jest kształtowany przez ludzi, zarówno jednostki jak i zbiorowości poprzez ich wyobrażenia, działania czy też sposoby organizacji stosunków społecznych. W dalszym ciągu rozważań stawiana jest jednak bardziej dyskusyjna teza o zasadniczej odmienności koncepcji miejsca w stosunku do tradycyjnego ujęcia społeczności lokalnej. Ta ostatnia kojarzona jest przede wszystkim z jedną ze skal porządku społecznego, podczas gdy miejsce jest przedmiotem oddziaływań podmiotów ulokowanych także w innych skalach, np. krajowej (aparat władzy, instytucje administracyjne), czy też globalnej (korporacje ponadnarodowe, stowarzyszenia i organizacje międzynarodowe), itp. Wydaje się zatem, że problematyka miejsca prowadzi do swoistego unieważnienia problematyki lokalności przede wszystkim w kontekście globalizacji. Omawiani autorzy nie podzielają jednak tak radykalnego stanowiska.

${ }^{8}$ M. Woods, Political articulation: the modalities of new critical politics of rural citizenship, [w:] Handbook of Rural Studies, s. 437-471.

${ }_{9}$ M. Lubaś, Przestrzenne skale odtwarzanie miejsca. Analiza społecznej organizacji przestrzeni Wnukowski zachodniej Macedoni, [w:] Społeczne tworzenie miejsc. Globalizacja, etniczność, władza, pod red. A. Bukowskiego, M. Lubasia, J. Nowaka, Wydawnictwo Uniwersytetu Jagiellońskiego, Kraków 2010.

${ }^{10}$ P. Berger, T. Luckman, Społeczne tworzenie rzeczywistości, Wydawnictwo Naukowe PWN, Warszawa 2010. 
Z jednej strony mają świadomość tego, że w dobie społeczeństwa lokalnego trudno mówić o istnieniu społeczności lokalnych jako jakichś odizolowanych od innych nurtów życia społecznego enklaw. Z drugiej jednak strony wskazują - powołując się na koncepcję Giddensa - że współczesne miejsca (ów współczesny ekwiwalent „tradycyjnej” lokalności) są kształtowane przez rozmaite czynniki i odniesienia ulokowane przede wszystkim poza nimi. W tym więc sensie koncepcja miejsca nie tyle unieważnia koncepcję lokalności, ile nadaje jej bardziej złożone znaczenie z uwagi na nacisk, jaki położony zostaje na swoistą rolę i znaczenie czynników pozalokalnych. Można zatem powiedzieć, że koncepcja miejsca to przystosowana niejako do ram społeczeństwa zglobalizowanego koncepcja lokalności (społeczności lokalnej).

Przyjmując taka perspektywę warto zwrócić uwagę na bardziej konkretne nurty rozważań związanych z problematyką miejsca. Można w tym kontekście wskazać np. na rozważania dotyczące procesów tzw. kształtowania miejsca (place shaping). W tej perspektywie chodzi przede wszystkim o analizę takich działań, które prowadzą do zmiany obrazu jakiejś społeczności (miasta, regionu, wsi, czy innego rodzaju terytorium). Autor tych rozważań zwraca uwagę, że ta koncepcja sytuuje „miejsce” w ramach społeczeństwa sieciowego, tworzącego ramy nie dla władzy autorytarnej, czyli narzucającej określone rozstrzygnięcia, ale raczej władzy wytwarzającej (generative) określone rozwiązania w toku wzajemnych oddziaływań na siebie podmiotów funkcjonujących $\mathrm{w}$ określonej sieci ${ }^{11}$. W tym sensie przekształcane miejsce nie jest ujmowane jako powstała struktura, ale raczej jako konstrukcja społeczna, która podlega procesom ciągłego kształtowania i przekształcania stanowiąc jednocześnie swoisty problem sporu pomiędzy uczestnikami wspomnianej sieci ${ }^{12}$.

W nieco inny sposób prowadzą swoje rozważania socjologowie australijscy ${ }^{13}$. Na początek warto może w całości przytoczyć definicję „miejsca”, jaką posługują się w swoim rozumowaniu. Jak pisze Frank Vanclay:

11 M. Shucksmith, Disintegrated rural development? Neoendogenous rural development, planning and place shaping in diffused power contexts, "Sociologia Ruralis" 2010, z. 1 (50), s. 1-14.

12 Por. szerzej na ten temat: M. Klekotko, K. Gorlach, Miejsce, lokalność, globalizacja: Przyczynek do problematyki socjologii wsi (i nie tylko) w społeczeństwie ponowoczesnym, [w:] Obszary wiejskie w Polsce: różnorodność i procesy różnicowania, pod. red. Hanny Podedwornej i Andrzeja Pilichowskiego, Wydawnictwo IFiS PAN, Warszawa 2011, 25-55.

${ }^{13}$ Making Sense of Place. Exploring Concepts and Expressions of Place through Different Senses and Lenses, pod red. F. Vanclay, M. Higgins, A. Blackshaw, National Museum of Australia, Canberra 2008. 
Miejsce jest w sumie postrzegane jako fragment przestrzeni, zawierający określone znaczenia (podkr. nasze - K.G.; P.N; M.K.). Zatem pojęcie miejsca odnosi się bardziej do znaczeń, które są przyporządkowywane określonemu fragmentowi przestrzeni, aniżeli do fizycznych charakterystyk owego fragmentu przestrzeni, czyli określonej lokalności ${ }^{14}$.

Skupmy się przez moment na przytoczonej powyżej definicji. Jak widać mamy tutaj do czynienia z nieco innym rozstrzygnięciem problemu relacji określenia „miejsca” do używanego wcześniej pojęcia lokalności (społeczności lokalnej). Na czym ta odmienność polega? Koncepcja miejsca nie jest tutaj proponowana jako współczesny substytut koncepcji społeczności lokalnej (lokalności). Wyraźnie natomiast podkreślony jest ich komplementarny charakter. Z jednej bowiem strony lokalność to tylko fizyczny aspekt określonego fragmentu przestrzeni. Z drugiej natomiast - „miejsce” to zespół znaczeń, jakie powiązane są ze wskazanymi wyżej fizycznymi charakterystykami. To właśnie sprawia, że koncepcja miejsca staje się szerokim, pojemnym pojęciem, dającym możliwość wyodrębniania w nim rozmaitych węższych znaczeń. Owe węższe znaczenia związane są np. z rozmaitymi typami narracji, jakimi w odniesieniu do rozmaitych fizycznych charakterystyk, a więc przejawów lokalności, mogą się posługiwać rozmaite „podtypy” kategorii społecznych. Jak twierdzi się:

Określone „podtypy” kategorii społecznych, na przykład dzieci, kobiety itp. mogą kreować specyficzne odniesienia do konkretnych miejsc, na przykład poprzez opowiadane historie, osobiste oceny, symbole i rytuały, pieśni, sposoby rozumienia, fizyczny kontakt, dźwięki czy też ciszę (milczenie) ${ }^{15}$.

Ważną kategorią w tym kontekście stają się przedstawiciele tzw. ludności tubylczej, do której to kategorii można zaliczyć np. zarówno ludność rodzimą (np. australijskich Aborygenów, czy amerykańskich Indian), jak również osiadłych w danej wsi z dziada pradziada rolników, czy też mieszkańców od kilku pokoleń związanych z danym miastem czy jego dzielnicą. Takie długotrwałe zakorzenienie w określonej lokalności skutkuje bowiem specyficznym typem narracji i tworzeniem szczególnego typu znaczeń w odniesieniu do określonych fizycznych charakterystyk miejsca. W tym obszarze mieszczą się także kwestie związane z poczuciem utraty określonego miejsca (np. w wyniku napływu nowych mieszkańców, czy też po prostu z opuszcze-

${ }^{14}$ F. Vanclay, Place matters, [w:] Making Sense of Place...., s. 3.

15 M. Klekotko, K. Gorlach, Miejsce, lokalność, globalizacja..., s. 29. 
niem go z takich czy innych powodów). W pierwszym przypadku narracja ludzi „zakorzenionych” zderza się niejako czy też zostaje skonfrontowana z narracjami „przybyszów”. Z kolei w tej drugiej sytuacji można obserwować powstanie narracji tworzących np. wyidealizowany obraz „utraconego" miejsca. Przypadki emigrantów czy też przesiedleńców idealizujących kraj czy choćby tylko określone wsie, miasteczka czy społeczności związane np. ze wspomnieniami z dzieciństwa czy młodości, mogą stanowić instruktywny przykład.

Problematyka rozmaitych narracji wytwarzających różnorodne znaczenia w odniesieniu do miejsca w sposób szczególny wiąże się też z zagadnieniami emocji oraz kultury. Ta pierwsza dotyczy pewnego ogólniejszego podejścia do analizy zjawisk społecznych oraz procesów społecznej konstrukcji. W sposób niejako naturalny powiązane są one z „miejscem”, traktowanym $\mathrm{z}$ kolei w perspektywie swoistego życiowego doświadczenia ludzi ${ }^{16}$. Uczucia są naturalnymi niejako składnikami ludzkiego doświadczenia. Gniew, frustracja, przyjaźń, miłość, fascynacja, radość, nienawiść, wrogość czy rezygnacja z tego właśnie powodu znajdują także odbicie $\mathrm{w}$ analizach właściwych naukom społecznym. Przejawiają się one w rozmaitych działaniach społecznych i mogą być obserwowane w różnych sytuacjach. W związku z tym można je także obserwować w procesach uspołeczniania przestrzeni, czyli właśnie tworzenia czy konstrukcji określonych miejsc. W tym kontekście uczucia mogą być związane z procesami konstruowania pamięci, która nadaje określonym miejscom specyficzne znaczenia. Emocje uwikłane są także w procesy rozumienia rozmaitych kwestii, istotnych dla nadawanych miejscom znaczeń. Jak wskazywaliśmy w innym opracowaniu:

(...) można tutaj wspomnieć o emocjach, jakie pojawiają się w kontekście zagadnień związanych z postrzeganiem i interpretacją problemów ekologicznych, zagrożeń środowiska, praw zwierząt, itp. Jeszcze inny sposób obecności emocji (...) to „opłakiwanie czegoś czy ubolewanie nad stratą”. Tę sytuację obserwować można np. w działaniach na rzecz określonej tradycji, charakteryzującej poszczególne miejsca, czy też działaniach na rzecz zachowania określonych gatunków roślin i zwierząt traktowanych jako element szeroko rozumianej aktywności proekologicznej. Jeszcze inny sposób obecności emocji w relacji człowiek-ludzie-społeczeństwo jest związany z kategorią przynależności. Wszyscy w jakiś sposób „przynależymy” do

${ }^{16}$ J. H. Turner, J. E. Stets, Socjologia emocji, Wydawnictwo Naukowe PWN, Warszawa 2009; Emotion, Place and Culture, pod red. M. Smith, J. Davidson, L. Cameron, L. Boni, Ashgate, Farnham-Burlington 2009. 
określonych fragmentów przestrzeni. Jesteśmy związani poprzez (...) fakt urodzenia czy zamieszkiwania z określonym miastem czy wioską. Ta więź może mieć także charakter czysto symboliczny, kiedy jesteśmy na przykład tylko członkami klubu czy stowarzyszenia skupiającego osoby w jakiś sposób związane (poprzez urodzenie, poprzednie zamieszkanie albo tylko poprzez czysty sentyment) z określonym miejscem (wsią, miastem, miasteczkiem, regionem, itp.). Można wreszcie realizować (...) swoją relację z określonym miejscem po prostu poprzez zachwyt czy oczarowanie. Oznacza to przede wszystkim, że istotnym elementem działań, które mogą przybierać rozmaity kierunek i charakter, jest jakiś rodzaj fascynacji, wynikający na przykład z pewnych naturalnych czy też społeczno-kulturowych (albo jedno i drugie) walorów charakteryzujących określone miejsce (...). Typowym przykładem (...) może być „zauroczenie góralszczyzną” (...). W tym jednak kontekście możliwe są także emocje negatywne (...) wrogość czy nienawiść do określonego miejsca, jak w wielu przypadkach byłych więźniów obozów koncentracyjnych do miejsc, gdzie spędzili „najgorszy” czy „najbardziej koszmarny” okres swojego życia ${ }^{17}$.

Kolejne - obok problematyki emocji - zagadnienia związane z koncepcją miejsca pojawiają się w związku z analizą rozmaitych inicjatyw, strategii postępowania czy też działań, które za punkt odniesienia przyjmują określony fragment przestrzeni oraz powiązane z nim elementy kulturowe (tradycje, znaczenia, itp.). Dobrym chyba przykładem będzie w tym momencie problem pewnego specyficznego aspektu systemu żywnościowego, jaki tworzą tak zwane produkty lokalne czy regionalne. W literaturze przedmiotu można odnaleźć wiele analiz, w których produkcja artykułów spożywczych jest ujmowana jako fragment industrialnego procesu wytwarzania surowców rolnych, a następnie półfabrykatów czy gotowych produktów przeznaczonych dla masowego konsumenta. W perspektywie koncepcji produktów lokalnych produkcja żywności jest jednak traktowana jako wytwarzanie produktu dla konsumenta zainteresowanego specyfiką konkretnego towaru, z uwzględnieniem w nim nawiązania do lokalnej („miejscowej”) tradycji i wynikających z niej znaczeń ${ }^{18}$. W polskim kontekście można tu chyba przywołać przypadek owczego sera zwanego oscypkiem, tradycyjnie związanego z regionem Podhala i kulturą góralską ${ }^{19}$.

${ }_{17}$ M. Klekotko, K. Gorlach, Miejsce, lokalność, globalizacja..., s. 30-31.

18 Naming Food After Places: Food Relocation and Knowledge Dynamics in Rural Development, pod red. M. Fonte, A. G. Papadopoulos, Ashgate, Aldershot 2010.

19 T. Adamski, K. Gorlach, One tradition many recipies: social networks and food production - the oscypek cheese case, [w:] Naming Food After Places..., s. 173-196. 
Rozważania powyższe mogłyby być jeszcze oczywiście kontynuowane, aby rozwinąć wiele bardziej szczegółowych wątków, związanych z problematyką miejsca. Nasze rozumowanie zmierza jednak w nieco odmiennym kierunku. Interesuje nas mianowicie, w jaki sposób problematyka miejsca i lokalności może zostać wkomponowana w analizę procesów przeobrażeń społeczeństwa, czyli w procesy społecznego rozwoju. Aby móc wyjść naprzeciw tak sformułowanemu programowi proponujemy pewną konkluzję, jaka może wynikać z przedstawionych wyżej rozważań. Pomijając pewne różnice, jakie zaobserwować można w przedstawionych wyżej wybranych koncepcjach „miejsca”, jedno wszakże wydaje się w nich wspólne. „Miejsce" staje się w kontekście społeczeństwa poddanego procesom globalizacji swoistym łącznikiem pomiędzy „lokalnością”, rozumianą jako zestaw pewnych charakterystyk fizycznych, dotyczących określonego fragmentu przestrzeni a sferą ponadlokalną. Chodzi właśnie o odniesienie do wartości, znaczeń czy działań ulokowanych w kontekście lokalności. Stawiamy tezę, że niejednoznaczną dla badaczy kwestię relacji pomiędzy lokalnością i miejscem można przezwyciężyć odwołując się do innego obecnego we współczesnym socjologicznym dyskursie pojęcia, jakim jest „glokalność”.

Obszerny, co nie znaczy oczywiście wyczerpujący, przegląd różnych stanowisk w tej kwestii został dokonany na łamach innych opracowań ${ }^{20}$. Tutaj natomiast zdecydowaliśmy się skupić jedynie na próbie rekonstrukcji pewnego modelu pojęciowego, który określić można mianem „społeczności glokalnej". Pojęcie glokalności pojawiło się w literaturze socjologicznej za sprawą Robertsona ${ }^{21}$, zaś w polskiej literaturze socjologicznej za sprawą Baumana $^{22}$. Pomijając to, co odmienne w obu koncepcjach, skupmy się przez moment na tym, co w nich można odnaleźć wspólnego. Chodzi o to, że przeobrażenia dokonujące się na poziomie lokalnym zachodzą obecnie w dużej mierze pod wpływem zjawisk i procesów globalnych. Taka jednostronność nie jest jednak charakterystyczna dla koncepcji, w których podkreśla się raczej wzajemny wpływ, czy też zwrotne relacje pomiędzy procesami

${ }^{20}$ M. Klekotko, K. Gorlach, Miejsce, lokalność, globalizacja..., s. 34-49; M. Klekotko, Rozwój po śląsku. Procesy kapitalizacji kultury w śląskiej społeczności górniczej, Wydawnictwo Uniwersytetu Jagiellońskiego, Kraków 2012.

${ }_{21}$ R. Robertson, Globalization: Social Theory and Global Culture, Sage Publications, London -Thousand Oaks-New Delhi 1992.

${ }^{22}$ Z. Bauman, Glokalizacja, czyli komu globalizacja a komu lokalizacja, „Studia Socjologiczne” 1997, z. 3, s. 53-70. 
globalnymi i lokalnymi. Przykładów takich ujęć można szukać w pracach Robertsona $^{23}$, Khondkera ${ }^{24}$ czy Giddensa ${ }^{25}$. Według pierwszego ze wskazanych autorów glokalizacja to proces „uniwersalizacji partykularyzmów oraz jednocześnie partykularyzacji uniwersalizmów", czyli - innymi słowy - wynoszenia na poziom globalny określonych wartości czy znaczeń lokalnych przy równoczesnym przełamywaniu się zjawisk i procesów globalnych na poziomie lokalnym. Khondker z kolei, wskazując na podobne procesy, określa je mianem makro- oraz mikroglobalizacji. Najdalej w swoich rozważaniach posuwa się natomiast Giddens, który wręcz stwierdza, że glokalizacja jest tym procesem, który powoduje swoisty renesans lokalności w globalizującym się społeczeństwie.

Pojęcie glokalizacji bywa także używane w innym nieco kontekście. Chodzi w nim mianowicie nie tyle o pewną koncepcję analityczną, która ma służyć opisowi i wyjaśnianiu rozmaitych zjawisk i procesów społecznych, ile o swoisty projekt o charakterze aplikacyjnym. W takiej perspektywie lokalizacja dotyczy procesów dynamicznej równowagi pomiędzy zasobami ulokowanymi w określonych społecznościach czy społeczeństwach oraz na poziomie ponadnarodowym (globalnym). Oto jak zostaje ona ujęta: „Celem glokalizacji jest ustanowienie powiązań pomiędzy korzyściami wymiaru globalnego - w postaci technologii, informacji i ekonomii - a lokalnymi realiami, przy jednoczesnym formowaniu oddolnego systemu współrządzenia (governance) globalizacją, opartego na większej równości w dystrybucji zasobów i na prawdziwym społecznym i kulturowym odrodzeniu znajdującej się w niekorzystnej sytuacji ludności"26.

Inny wątek, jaki pojawia się w rozważaniach dotyczących glokalizacji, skoncentrowany jest na kierunkach przemian społeczności lokalnych poddanych procesom globalizacji ${ }^{27}$. Pierwszy z nich określony zostaje mianem scenariusza kosmopolitycznego. Istotą jego jest zanik specyfiki lokalności i „rozpuszczenie” się niejako społeczności lokalnej w zglobalizowanym społe-

${ }^{23}$ R. Robertson, Glocalization: Time-space and homogenaty-heterogenity, [w:] Global Modernities, pod. red. M. Featherstone, S. Lash, R. Robertson, Sage, London 1995, s. 25-44.

${ }^{24}$ H. H. Khondker, Glocalization as globalization: evolution of a sociological concept, "Bangladesh e-Journal of Sociology" 2004, z. 1 (2).

25 A. Giddens, Nowoczesność i tożsamość, „Ja" i społeczeństwo w epoce późnej nowoczesności, tłum. A. Szulżyńska, PWN, Warszawa 2001.

${ }^{26}$ S. Nigro, Glocalization. Research Study and Policy Recommendations, CEFRE \& Glocal Forum, Rome 2003, s. 5.

${ }^{27}$ M. Klekotko, Rozwój po ślq̨sku... 
czeństwie. Scenariusz drugi określić można mianem fundamentalistycznego zaścianka, w ramach którego społeczność lokalna przyjmuje swoistą obronną postawę w obliczu zjawisk i procesów globalizacji. Wreszcie trzeci scenariusz to procesy tworzenia się społeczności lokalnych nowego typu. Warto przyjrzeć się przez moment bliżej każdemu spośród wskazanych scenariuszy.

Zasadniczymi elementami scenariusza kosmopolitycznego są następujące charakterystyki. Przede wszystkim z uwagi na procesy globalizacji wzrasta w sposób istotny zróżnicowanie społeczne, które kiedyś obserwowano jako ścieżkę rozwoju społeczeństwa masowego ${ }^{28}$. Na proces ten składa się przynajmniej kilka ważnych i znaczących komponentów. Chodzi przede wszystkim o bardzo intensywny przepływ idei, norm czy wartości, oddziaływujący z jednej strony na formowanie podstaw poznawczych uczestników życia społecznego, z drugiej zaś - na więzi łączące poszczególnych aktorów. $W$ procesie modernizacji, stanowiącym historycznie pierwsze przełamanie tradycyjnego układu społecznego, wskazywano w tym kontekście na procesy industrializacji, urbanizacji oraz instytucjonalizacji. Globalizacja wzmacnia tę tendencję, z jednej strony intensyfikując procesy ruchliwości, także - a może przede wszystkim - przestrzennej, z drugiej zaś - uwypuklając tendencje indywidualistyczne, wypierające identyfikacje terytorialne i odniesienia do tradycji. Socjologowie próbują analizować te procesy oraz ich przejawy formułując np. koncepcje społeczności bezlokalnych $^{29}$, wspólnot osobistych ${ }^{30}$, czy też wspólnot zainteresowań ${ }^{31}$. To co najbardziej istotne to fakt, że określone przestrzenne terytorium przestaje być podstawą odniesienia dla tworzących się więzi społecznych. W ten sposób w miejsce wspólnoty pojawiają się sieci ${ }^{32}$. Można zatem powiedzieć, że w rezultacie naszkicowanych procesów przechodzimy od społeczeństwa wspólnot do społeczeństwa sieci.

${ }^{28}$ M. Klekotko, K. Gorlach, Miejsce, lokalność, globalizacja..., s. 39-40; M. Klekotko, Rozwój po śląsku...

${ }_{29}$ P. Starosta, Poza metropoliq. Wiejskie i małomiasteczkowe społeczności lokalne a wzory porzq̨dku makrospołecznego, Wydawnictwo Uniwersytetu Łódzkiego, Łódź 1995.

${ }_{30}$ Tegoż, Globalizacja i nowy komunitaryzm, [w:] Niepokojąca współczesność, pod. red. A. Miszalskiej i K. Kowalewicza, Wydawnictwo Uniwersytetu Łódzkiego, Łódź 2001.

${ }^{31}$ Tamże.

${ }^{32}$ M. Castells, Społeczeństwo sieci, tłum. M. Marody i in., Wydawnictwo Naukowe PWN, Warszawa 2007. 
Drugi ze wspomnianych scenariuszy, określany mianem „fundamentalistycznego zaścianka", zawiera wprawdzie podobną diagnozę, dotyczącą obserwowanych procesów społecznych, ale jednocześnie w jego ramach zostaje zwrócona uwaga na zupełnie odmienne konsekwencje. Scenariusz przemian jest tutaj w gruncie rzeczy aż nadto prosty i jednocześnie łatwy do wyjaśnienia. Otóż postępująca atomizacja oraz indywidualizacja posiadają raczej negatywne następstwa. Obydwa te procesy skutkują przede wszystkim chaosem oraz niepewnością w relacjach społecznych i w konsekwencji wytwarzają wśród uczestników życia społecznego poczucie lęku, braku stabilności, poczucie wzrastającej niepewności i związanego z tym dyskomfortu czy wręcz frustracji. Wszystko to powoduje, że reakcja na tę sytuację przyjmuje charakter swoistego powrotu do przeszłości. Jak stwierdzaliśmy już w innym opracowaniu:

Stąd rodzi się potrzeba odtworzenia tradycyjnej społeczności lokalnej, stawiającej na wartości wspólnotowe, społeczną spójność i relatywną jednorodność oraz ekskluzywny i samowystarczalny typ organizacji społecznej. Konstruowana w ten sposób nowa - stara tożsamość ma przywrócić poczucie bezpieczeństwa ontologicznego oraz nadać od nowa sens rzeczywistości społecznej. Jednak taki scenariusz prowadzi jednocześnie do marginalizacji we współczesnym szybko zmieniającym się społeczeństwie, przyczyniając się ponadto do powstania rozmaitych „małych nacjonalizmów”, ruchów eskapistycznych czy postaw i zachowań ksenofobicznych ${ }^{33}$.

Pojawia się więc w tym kontekście określenie „wspólnot opozycyjnych”34, czy „destruktywnego Gemeinschaft”35, „powrotu do źródeł”36, „ciasnego nacjonalizmu” 37 , czy wreszcie po prostu „fundamentalizmu”38.

\section{Nowa społeczność lokalna}

Pora przejść do charakterystyki trzeciego scenariusza. Istota jego polega na wskazaniu, że społeczności lokalne istnieć mogą nadal we współczesnym zglobalizowanym społeczeństwie, tyle że oczywiście nie w tradycyj-

33 M. Klekotko, K. Gorlach, Miejsce, lokalność, globalizacja..., s. 40.

${ }_{34}$ M. Castells, dz. cyt.; P. Starosta, Globalizacja i nowy komunitaryzm..., s. 57.

35 R. Sennett, The Fall of Public Man, W.W.Norton \& Company, New York 1992.

${ }^{36}$ E. Wnuk-Lipiński, Świat międzyepoki. Globalizacja, demokracja, państwo narodowe, Wydawnictwo ZNAK-ISP PAN, Kraków 2004.

${ }^{37}$ U. Beck, Władza i przeciwwładza w epoce globalnej. Nowa ekonomia polityki światowej, Wydawnictwo Naukowe SCHOLAR, Warszawa 2005.

${ }^{38}$ P. McMichael, Development and Social Change A Global Perspective, Pine Forge Press, Thousand Oaks-London-New Delhi 2004 (wydanie 3). 
nej postaci. Podobnie jak i w poprzednim przypadku pojawia się tutaj wiele rozmaitych określeń. Mowa jest zatem o „społecznościach inkluzywnych”, społecznościach potencjalnych ${ }^{40}$, społecznościach zmodernizowanych ${ }^{41}$, czy też społecznościach komunitarystycznych ${ }^{42}$. Nie analizując szczegółowo i kolejno każdej z tych koncepcji, spróbujemy w sposób bardziej systematyczny przyjrzeć się charakterystykom tak ujętej „nowej społeczności lokalnej”, które odróżniają ją od społeczności tradycyjnych.

Pierwsza z tych charakterystyk dotyczy tego, iż lokalne społeczności we współczesnym świecie są społecznościami otwartymi. Oznacza to, że warunkiem ich trwania i rozwoju jest umiejętność wykorzystywania możliwości, jakie stwarza globalizacja. W tym kontekście niezwykle ważną rolę odgrywają procesy mobilizacji. Skupienie wokół określonego celu oraz zorientowanie na wykonanie zdefiniowanych zadań wydają się stanowić podstawę formowania więzi i podtrzymywania relacji społecznych między członkami tworzącymi współczesną społeczność lokalną. Tym samym społeczności lokalne przypominałyby w jakimś sensie ruchy społeczne z uwagi na ich z jednej strony ulotną naturę, z drugiej zaś - wyraźne zorientowanie jeżeli nie na osiągnięcie jakiegoś pragmatycznego celu, to przynajmniej na działanie na rzecz świadectwa w odniesieniu do określonych idei czy wartości. Byłyby to zatem w jakiś sposób społeczności zadaniowe. Taki charakter nowych społeczności lokalnych wpływa także na zdecydowaną dominację sfery publicznej w obszarze ich funkcjonowania i podejmowanych działań. Nie są one bowiem oparte na tradycji czy też jakimś rodzaju wspólnoty związanej z sąsiedztwem, ale właśnie na jej innym rodzaju, jakim jest wspólnota preferencji czy zainteresowań albo wręcz wspólnota interesu. Ta ostatnia kwestia oddziałuje także na nowe rozumienie przestrzennego aspektu społeczności lokalnych. Musi zostać ono potraktowane nie jako tradycyjnie wspólnotowy obszar, ale raczej jako terytorium, gdzie obowiązują

39 A. Etzioni, Next: The Road to the Good Society, Basic Books, New York 2001.

40 P. Starosta, Poza metropolia...

${ }^{41}$ A. Komendera, U podstaw zbiorowości lokalnych, [w:] Zbiorowości terytorialne i więzi społeczne: studia i szkice socjologiczne dedykowane profesorowo Wacławowi Piotrowskiemu w siedemdziesiąta rocznice urodzin, pod red. P. Starosty, Wydawnictwo Uniwersytetu Łódzkiego, Łódź 1995.

${ }^{42}$ H. Tam, Communitarianism. A New Agenda for Politics and Citizenship, MacMillan Press, London 1998; A. Etzioni, dz. cyt.; H. J. Rubin; I. Rubin, Community Organizing and Development, Allyn and Bacon, Boston 2001. 
określone normy, wartości, reguły czy prawa. Jak pisaliśmy bowiem gdzie indziej: „W społeczności lokalnej nowego typu ważna jest (...) nie sąsiedzka zażyłość, ale bliskość funkcjonalna, związana ze wspomnianą realizacją określonych celów"³.

Nowe społeczności lokalne charakteryzują się także swoistym typem więzi. Zanim poddamy krótkiej refleksji ten aspekt ich charakterystyki trzeba nadmienić, że właśnie więzi przestają w tym przypadku być szczególnym, specyficznym czy też w jakimś sensie absolutnie wyróżniającym je czynnikiem. Można powiedzieć, że jeśli chodzi o więzi to nowe społeczności lokalne raczej nie wyróżniają się specjalnie od innych form społecznego współistnienia członków społeczeństwa. Bardziej przypominają dobrowolne zrzeszenia, czy - opisane wyżej społeczności bliskości funkcjonalnej, aniżeli tradycyjne społeczności lokalne, do których wchodziło się nie tyle poprzez akt podmiotowej, jednostkowej decyzji, ile poprzez fakt urodzenia w określonej rodzinie, osadzonej z kolei w określonym sąsiedztwie. Społeczności lokalne nowego typu pojawiają się przede wszystkim w obrębie sfery publicznej. To także wpływa na charakter istniejących w nich więzi. Mniejszą wagę przywiązuje się w nich do kontroli wszystkich aspektów życia ludzkiego, bardziej zaś kładzie się nacisk na zaangażowanie typu obywatelskiego właśnie obserwowalne w sferze publicznej. Z drugiej jednak strony nie można w tym kontekście nie wspomnieć o procesach upubliczniania jeśli można to tak określić - czyli swoistego przenoszenia ze sfery prywatnej (wyłączonej z zewnętrznych kontroli) do sfery publicznej, poddanej jakimś rodzajom procesów kontrolnych rozmaitych zjawisk, tradycyjnie uznanych za obszar prywatności czy wręcz intymności. W tym kontekście można np. wskazać problem przemocy w rodzinie, czy prawo do ujawniania swojej orientacji seksualnej, przy jednoczesnym domaganiu się tolerancji dla niej, itp. 0 tych zjawiskach należy pamiętać, jednak nie są one zasadniczym wątkiem naszych rozważań w ramach tego opracowania.

Kontynuując nasz wątek chcielibyśmy przywołać sformułowania, prezentowane już przy innej okazji. Otóż stawiamy tezę, że:

(...) idea społeczeństwa obywatelskiego leży u podstaw modelowej społeczności lokalnej nowego typu. Przestrzeń publiczna, w której owa społeczność istnieje, to właśnie obszar działania obywatelskiego, które rozumiane jest w tym przypadku jako zespól zaangażowanych osób oraz instytucji, które wraz z nimi podejmują

${ }^{43}$ M. Klekotko, K. Gorlach, Miejsce, lokalność, globalizacja..., s. 42. 
odpowiedzialność za funkcjonowanie społeczności, nie tylko obecnie, ale i z myślą o przyszłych pokoleniach. Można zatem powiedzieć, że istotą społeczności lokalnej nowego typu staje się obywatelskie uczestnictwo w działaniach na rzecz jej rozwoju ${ }^{44}$.

Zapamiętajmy to stwierdzenie, bo stanowi ono istotny punkt wyjścia do rozważań zawartych w następnym fragmencie naszego opracowania.

Zanim jednak do tego przejdziemy chcielibyśmy jeszcze przez jakiś czas pozostać przy omówieniu kwestii relacji pomiędzy nową społecznością lokalną a społeczeństwem obywatelskim. Nie wszystkie działania obserwowane w społeczności lokalnej są przejawami społeczeństwa obywatelskiego. Pogawędki pod kościołem, czy wspólne picie piwa w miejscowym barze (albo i pod miejscowym sklepem) raczej nie należą do tej sfery. Coraz częściej też nie należą do tego np. wspólne żniwa w społeczności wiejskiej, a więc wspólne podejmowanie pewnych czynności zwanych pracą. Nie znaczy to oczywiście, że żniwa kompletnie przestały być widoczne we współczesnej wsi polskiej, choć dzieje się tak w wielu społecznościach i z tym mamy do czynienia z uwagi na postępujące procesy dezagraryzacji gospodarki wiejskiej, krajobrazu i sposobu życia jej mieszkańców. Ale nawet tam, gdzie odbywają się one wciąż jeszcze i zapewne długo będą się jeszcze odbywać, przybrały zupełnie inny charakter. Nie jest to już wydarzenie z zakresu wspólnej pracy, ale praca pojedynczych, wyspecjalizowanych pracowników, posługujących się coraz bardziej wyrafinowanym sprzętem i obsługujących własne gospodarstwa bądź świadczących usługi współmieszkańcom. Badania prowadzone na przełomie stuleci na losowo-celowej próbie właścicieli indywidualnych gospodarstw rolnych w Polsce, ukazały dramatyczny spadek pracy w systemie wzajemnej pomocy sąsiedzkiej (tzw. „praca na odrobek" ${ }^{45}$. W tym między innymi sensie „dawne” społeczności lokalne stają się w coraz większym stopniu po prostu lokalnymi zbiorowościami, pod wpływem procesów modernizacji oraz globalizacji. Jednocześnie procesy te współcześnie sprzyjają procesom ich swoistej reintegracji, w których społeczności lokalne przyjmują bardziej charakter zrzeszeń obywatelskich, opierając swoje funkcjonowanie na otwarciu na świat zewnętrzny oraz

44 Tamże, s. 43.

45 K. Gorlach, W poszukiwaniu równowagi. Polskie rodzinne gospodarstwa rolne w Unii Europejskiej, Wydawnictwo Uniwersytetu Jagiellońskiego, Kraków 2009, s. 104. 
inkluzywnym charakterze stosunków społecznych. Ten nowy lokalizm jest testowany przede wszystkim w procesach rozwoju społecznego, o czym będzie mowa w następnym fragmencie naszych rozważań.

\section{Nowe ujęcie rozwoju społecznego}

W ramach tego opracowania nie pretendujemy oczywiście do omówienia różnych koncepcji zmiany społecznej, czy też rozwoju społecznego, wychodząc z założenia, że syntetyzująca literatura w języku polskim jest wysoce instruktywna dla czytelnika zainteresowanego taką historyczno-teoretyczną problematyką ${ }^{46}$. Czując się w taki sposób zwolnieni z tego typu prezentacji oraz z uwagi także na ograniczone ramy tego szkicu, chcielibyśmy skoncentrować się tylko na omówieniu dwóch koncepcji, które są szczególnie istotne w kontekście głównego wątku naszych rozważań, jakim jest rozwojowy dylemat dotyczący myślenia i działania w skali lokalnej i globalnej. Uważamy bowiem, że ten dylemat zostaje właściwie postawiony i jednocześnie zawiera sugestię rozwiązania w koncepcji rozwoju neo-endogennego, oraz rozwoju zrównoważonego (sustainable development). Tym właśnie zagadnieniom jest poświęcona obecna, ostatnia część naszego opracowania. Ważne jest przy tym jeszcze jedno zastrzeżenie. Otóż także te koncepcje będą przedstawione w sposób daleki od wyczerpującego opisu i analizy. Skupimy się raczej na zasygnalizowaniu ich głównych przesłanek teoretycznych oraz na wynikającej z nich wizji rozwoju, skupionej przede wszystkim na jego mechanizmach. Dodatkowym czynnikiem, który braliśmy pod uwagę uzasadniając ograniczenie naszych rozważań do zasadniczych przesłań tych właśnie koncepcji jest to, że w obydwu z nich mocno kładzie się nacisk na problematykę lokalną, problematykę lokalnych społeczności, czy problematykę udomowionych miejsc w przestrzeni społecznej.

Najbardziej syntetyczną i jednocześnie klarowną prezentację można odnaleźć - naszym zdaniem - w artykułach brytyjskiego socjologa wsi Christophera Ray ${ }^{47}$. Fundamentalna idea tej koncepcji rozwoju oparta jest - w jego opinii - na dwóch przesłankach. Z jednej strony jest to ów element

${ }^{46}$ Por. np.: P. Sztompka, Socjologia zmian społecznych, Wydawnictwo ZNAK, Kraków 2005; Tegoż, Socjologia. Analiza społeczeństwa, wydanie drugie, Wydawnictwo ZNAK, Kraków 2012, s. 495-614.

47 C. Ray, Neo-endogenius rural development in the EU, [w:] Handbook of Rural Studies..., s. 278-291. 
endogenny, który zawiera przesłanie, że animacja procesów rozwojowych musi być oparta na oddolnej, lokalnej właśnie inicjatywie, jak również musi wykorzystywać podejście znane w literaturze naukowej i praktyce społecznej jako bottom-up approach. Z kolei komponent „neo” - wedle określenia Ray’a - wskazuje na ważną rolę, jaką w tym procesie muszą odgrywać czynniki pozalokalne (extralocal). Nie da się bowiem, jak podkreśla Ray, zagwarantować integralności rozwoju na poziomie lokalnym, odcinając społeczności lokalne od relacji ze światem zewnętrznym, tak jak można to odnaleźć np. w niektórych skrajnie ujmowanych koncepcjach rozwoju endogennego ${ }^{48}$. Rozwój neo-endogenny, dalej, posiada dwie najbardziej istotne charakterystyki. Po pierwsze, wszelkie działania na rzecz rozwoju ekonomicznego, ale nie tylko, są zorientowane na maksymalizowanie zgromadzenia korzyści w obrębie określonego terytorium lokalnego. Odbywa się to dzięki waloryzacji i wykorzystaniu lokalnych zasobów, zarówno naturalnych, jak i ludzkich. Po drugie jednak owa działalność ulega - by użyć określenia Ray ‘a ${ }^{49}$ - kontekstualizacji w tym sensie, iż jest skoncentrowana na potrzebach, możliwościach i perspektywach życiowych lokalnej populacji. Podkreśla się także w tym kontekście uczestnictwo członków lokalnej społeczności w kształtowaniu i wdrażaniu praktyk rozwojowych oraz wykorzystywanie lokalnych środowiskowych i społecznościowych wartości. W tej perspektywie podkreśla się także zasadę wpływu społeczności na własną przyszłość, zarówno poprzez wspomniane już wyżej wykorzystanie lokalnych zasobów, jak i tworzenie mechanizmów trwałego rozwoju, zainicjowanego niejednokrotnie przez jakiś zewnętrzny bodziec.

Omawiając kwestie wspomnianych wyżej fundamentalnych idei i charakterystyk rozwoju neo-endogennego, Ray wskazuje także na jego - jak to określa - teoretyczne zasady ${ }^{50}$. Są to ogólne i powiązane ze sobą podejścia analityczne, które określa kolejno mianem: społecznej ekonomii (social economy), ekonomicznej koordynacji (economic coordination) oraz wielopoziomowego współrządzenia (multi-level governance). Pierwsze z nich wskazuje na konieczność takiego ujęcia procesów ekonomicznych, które analizowane

${ }^{48}$ Por. na ten temat m.in. K. Krzysztofek, M. S. Szczepański, Zrozumieć rozwój. Od społeczeństw tradycyjnych do informacyjnych, Wydawnictwo Uniwersytetu Śląskiego, Katowice 2002; M. Klekotko, Rozwój po śląsku. Procesy kapitalizacji kultury w ślq̨skiej społeczności górniczej, Wydawnictwo Uniwersytetu Jagiellońskiego, Kraków 2012.

${ }^{49}$ C. Ray, dz. cyt., s. 278.

50 Tamże, s. 279-283. 
są zawsze w określonym społecznym kontekście. Dlatego też wszelkie inicjatywy i plany dotyczące zmian ekonomicznych, czy ekonomicznego rozwoju, muszą w każdym przypadku uwzględniać lokalny kontekst, potrzeby mieszkańców oraz możliwe skutki podejmowanych działań. Z kolei ekonomiczna koordynacja mająca przeciwdziałać negatywnym skutkom nowoczesnego, globalnego kapitalizmu, takim jak: indywidualizacja oraz degradacja środowiska naturalnego i kultury, zwraca uwagę na konieczność takiej konstrukcji reguł wzajemności, redystrybucji i wymiany rynkowej, które winny działać w interesie lokalnych społeczności. Stąd właśnie ów terytorialny a nie sektorowy aspekt staje się istotnym elementem w koncepcji rozwoju neo-endogennego. Wielopoziomowe współrządzenie oznacza z kolei uwzględnianie różnych aktorów, zarówno lokalnych jak i pozalokalnych, funkcjonujących w ramach sieci, w których podejmowane są debaty oraz decyzje dotyczące tworzenia i wdrażania polityk rozwojowych.

Dodatkowym elementem charakterystyki koncepcji rozwoju neo-endogennego, prezentowanej przez Ray $a^{51}$, jest propozycja perspektyw badawczych, które są użyteczne w rozumieniu jej funkcjonowania. Skoncentrowane są one na zasadniczej charakterystyce tej koncepcji, jaką jest właśnie ujęcie procesów rozwoju w perspektywie terytorium. Chodzi tutaj o następujące tzw. plany (perspektywy): wewnętrzterytorialną, terytorialną w kontekście polityczno-administracyjnym oraz międzyterytorialną. W pierwszej z nich badacze koncentrują się na rekonstrukcji tzw. terytorialnego sposobu produkcji, strategicznym terytorialnym typie aktywności, roli i znaczeniu kapitału społecznego, formach partnerstwa i funkcjonowania ciał podejmujących decyzje, dotyczące rozwoju. Z kolei perspektywa terytorialna w kontekście polityczno-administracyjnym wskazuje na potrzebę analiz lokalnych inicjatyw rozwojowych w kontekście łańcucha zależności politycznych i administracyjnych, w których istotną rolę odgrywają administracje państw narodowych oraz szerszych ponadnarodowych struktur (np. Unii Europejskiej). Ważną rolę pełnią tu procesy ewaluacyjne, stanowiące integralną część polityk rozwojowych. Wreszcie perspektywa międzyterytorialna to zwrócenie uwagi na relacje pomiędzy poszczególnymi jednostkami tery torialnymi, które są scenami procesów rozwoju. Ważne są tutaj kwestie pojawiania się bardziej trwałych powiązań w efekcie tych relacji oraz samej

51 Tamże, s. 283-290. 
zawartości owych relacji, które mogą przybierać rozmaity charakter i nieść w sobie rozmaite treści. Mogą np. sprowadzać się do przepływu dóbr oraz konsumentów. Mogą też jednak być kanałem przepływu rozmaitych wartości, treści kulturowych, treści budujących świadomość uczestnictwa w szerszych układach ekonomicznych, społecznych czy kulturowych. Wreszcie polegać mogą także na procesach regulacji oraz wzajemnego „uczenia się” rozmaitych metod działania i praktycznych rozwiązań.

Druga z wziętych pod uwagę koncepcji, czyli idea rozwoju zrównoważonego kojarzona jest przede wszystkim z problematyką środowiska naturalnego ${ }^{52}$. Literatura przedmiotu wskazuje tutaj na trzy sposoby ujęcia tej problematyki. Po pierwsze, środowisko naturalne obok zagadnień ekonomicznych i społecznych stanowi trzeci filar wspierający koncepcję rozwoju. Po drugie, idea rozwoju zrównoważonego zawiera się w obrębie zagadnień wyznaczonych przez rozwój ekonomiczny, społeczny oraz ochronę środowiska. Chodzi tutaj ni mniej ni więcej tylko o to, że zrównoważenie w procesach przemian odnosi się do takiego obszaru, gdzie wspomniane przeobrażenia zapewniają z jednej strony wzrost gospodarczy, z drugiej nie niszczą w sposób zasadniczy istniejącej tkanki społecznej, a dodatkowo nie prowadzą także do destrukcji zasobów naturalnych. Po trzecie wreszcie, chodzi tutaj o takie ujęcie rozwoju, którego obszarem granicznym jeśli można to tak określić - jest właśnie ochrona środowiska naturalnego, rozumiana jako niewyczerpywanie istniejących zasobów naturalnych. Przeobrażenia w zakresie ekonomicznym i społecznym dopuszczalne są zatem tylko do takiego poziomu, który nie uszczupla zasobów przyrody poddanej eksploatacji ${ }^{53}$.

Koncepcja rozwoju zrównoważonego wiąże się przede wszystkim z takim modelem rozwoju ekonomicznego, który jednocześnie jest przyjazny dla środowiska naturalnego, jak również, choć już raczej w mniejszym stopniu, dla społeczeństwa. Jednak zawarte we współczesnej literaturze przedmiotu wskazania znacznie poszerzają jej zakres. Przykładem takiego szerokiego określenia jest sformułowanie swoistego dekalogu społeczeń-

${ }^{52}$ Fragment poświęcony koncepcji rozwoju zrównoważonego oparty jest w dużej mierze na fragmentach innego naszego opracowania. Por. Krzysztof Gorlach, Marta Klekotko, Piotr Nowak, Rozwój społeczny - rozwój zrównoważony - postęp: przyczynek do rozwoju obszarów wiejskich, tekst niepublikowany, Kraków 2013.

53 J. A. Elliot, An Introduction to Sustainable Development, Routledge, London and New York 2013, s. 20-21. 
stwa zrównoważonego ${ }^{54}$. Zawarto tutaj kluczowe - zdaniem autorów - zasady konieczności podtrzymywania demokracji partycypacyjnej, subsydiarności, ekologicznej równowagi, pielęgnowania wspólnego dziedzictwa, idei różnorodności, idei praw człowieka, ochrony rynku pracy i dobrostanu gospodarstw domowych, bezpieczeństwa żywnościowego i osobistego, jak również ochrony przed ryzykiem związanym z globalnym rozwojem. Wbrew krytykom tak rozumiana demokracja partycypacyjna nie jest jednak stanem permanentnego referendum, które rodzi duże ryzyko zablokowania jakichkolwiek zmian, ale raczej procesem tworzenia struktur współrządzenia (governance). W tworzonej w ramach realizacji tej zasady sieci istotna rola przypada podmiotom lokalnym, przedstawicielom lokalnych, miejscowych (indogenous) społeczności.

Kolejna z wymienionych zasad określona jest mianem „pomocniczości” (subsidiarity). W jej obrębie zawarta jest idea sprzeciwu wobec zawłaszczania lokalnych zasobów i perspektywy rozwojowej przez dominujące podmioty ponadlokalne czy wręcz globalne. Filozofia pozytywnego myślenia w jej obrębie zwiera przesłanie, iż jakiekolwiek decyzje i działania mogą być podejmowane na poziomie lokalnym, tam właśnie powinny być podejmowane oraz gdziekolwiek ośrodek władzy może być ulokowanym na poziomie lokalnym, tam właśnie powinien zostać umieszczony.

Inna kwestia podejmowana w ramach dekalogu rozwoju zrównoważonego to zagadnienia równowagi ekologicznej. Wskazuje się w tym kontekście na pewne charakterystyki, które mogą stanowić o istocie społeczeństwa zrównoważonego. Przede wszystkim zwraca się uwagę na to, że rozmiar konsumpcji zasobów nie powinien przekraczać rozmiaru ich regeneracji. Oznacza to po prostu tyle, że nie można konsumować więcej niż można będzie odnowić.

Kolejny aspekt rozważanego problemu wiąże się z zachowaniem wspólnego dziedzictwa (common heritage). Skoncentrowane jest to wokół trzech aspektów tego zagadnienia. Przede wszystkim chodzi o to, aby zachować w stanie w miarę nieskażonym takie zasoby, jak: wodę, glebę, powietrze, lasy, zasoby mórz i oceanów, czyli wszystko to co wpływa na życie każdego człowieka. Idea ta obejmuje jednak także kulturę i wiedzę, jaką zgromadziły społeczeństwa, jak również wszystkie publiczne zasoby, które charakte-

${ }^{54}$ Alternatives to Economic Globalization. A Better World is Possible, pod red. J. Cavanagh, J. Mander, Berrett-Koehler Publishers, San Francisco 2004, s. 77-104 (wydanie drugie, poszerzone). 
ryzują poziom poczucia bezpieczeństwa osobistego i społecznego, a także zapewnienie zdrowia i osiągnięcia odpowiedniego poziomu wykształcenia. Z zachowaniem dziedzictwa powiązana jest blisko - w naszym przekonaniu - kwestia zróżnicowania. Co najbardziej istotne to fakt, że nie chodzi tu tylko o zróżnicowanie biologiczne, zapewniające odpowiednią pulę różnorodnych genów, użytecznych do reprodukcji organizmów roślinnych czy zwierzęcych i w tym sensie zachowania samo-regulujących się i samo-odnawiających się ekosystemów; ale też o zróżnicowanie ekonomiczne i kulturowe.

Problematyka zmiany i rozwoju we współczesnym społeczeństwie powiązana jest także z zagadnieniem praw człowieka. Tradycyjna perspektywa w tym zakresie, rozwijana przede wszystkim w społeczeństwach tzw. Zachodu, dotyczyła w gruncie rzeczy pewnego tylko fragmentu tej kwestii tj. nader wąsko rozumianych praw politycznych i obywatelskich. Skoncentrowane były one przede wszystkim wokół kwestii demokracji proceduralnej, swobody wypowiedzi, zrzeszania się, itp. Natomiast kwestia praw ekonomicznych, kulturalnych i społecznych, silnie uwypuklanych w ramach idei rozwoju zrównoważonego, dotyczy bardziej fundamentalnych kwestii, takich jak: prawo dostępu do bezpiecznej żywności i wody, prawo do zachowania tradycji i tożsamości kulturowo-społecznej, prawo do zabezpieczenia socjalnego i godziwego sposobu życia, itp.

Koncepcja rozwoju zrównoważonego kojarzona jest także z ideą równości, przeciwstawiającą się efektom globalizacji, które wskazują na poszerzanie się rozpiętości dochodowych zarówno w skali globalnej, jak i w poszczególnych społeczeństwach. Rozpiętości te dotyczą nie tylko różnic między tzw. „bogatymi” i „biednymi”, ale także między mężczyznami i kobietami, wielkimi korporacyjnymi gospodarstwami rolnymi i relatywnie niewielkimi gospodarstwami rodzinnymi, grupami etnicznymi dominującymi w danych społeczeństwach i imigrantami, itd. Obserwowane rozpiętości dochodowe i związane z tym przejawy braku społecznej sprawiedliwości powiązane są ponadto ze szczególnym przesłaniem koncepcji rozwoju zrównoważonego, jakim jest tzw. zasada „ostrożności” (precautionary principle). W tym kontekście zwraca się uwagę przede wszystkim na to, iż wprowadzane w procesach rozwojowych innowacje winny być na wstępie poddane procesowi oceny w perspektywie możliwych konsekwencji, które mogą mieć zarówno pozytywny, jak i negatywny charakter. 


\section{Konkluzje}

Koncepcje rozwoju neo-endogennego oraz rozwoju zrównoważonego są blisko ze sobą powiązane. Swego czasu sformułowana została nawet teza wskazująca na to, że rozwój neo-endogenny może być traktowany jako mechanizm rozwoju zrównoważonego ${ }^{55}$. Obecnie jednak chcielibyśmy tę tezę nieco przeformułować. Oczywiście koncepcja rozwoju neo-endogennego ( $w$ wersji przedstawionej w tym opracowaniu za Christopherem Ray`em) jest zaprezentowaniem pewnego mechanizmu rozwojowego (w dość jednak abstrakcyjnym języku), którego istotą jest pewien specyficzny sposób powiązania tego co lokalne z tym co globalne (czy jak to dokładnie określa Ray: pozalokalne). Warunkiem określonych zmian na poziomie lokalnym jest niejako wciągniecie w proces wykorzystywania zasobów lokalnych czynników i aktorów pozalokalnych oraz tworzenie relacji pomiędzy różnymi jednostkami lokalnymi na poziomie pozalokalnym (globalnym). Ważną rolę $\mathrm{w}$ funkcjonowaniu tego mechanizmu odgrywają też tradycyjni niejako aktorzy ze sfery administracyjno-politycznej (czyli państwo oraz jego rozmaite agendy, ale także ruchy, organizacje czy stowarzyszenia).

W tym kontekście koncepcja rozwoju zrównoważonego może zostać potraktowana jako idea wyposażona $\mathrm{w}$ jeszcze bardziej bogate treści w porównaniu z koncepcją rozwoju neo-endogennego. Jeżeli przypomnimy raz jeszcze krótko ów „dekalog zrównoważonego społeczeństwa” to możemy odnaleźć w nim dwa rodzaje elementów, albo wręcz nawiązując do stylizacji zaproponowanej przez Cavanagha i Mandera, dwa rodzaje przykazań. Z jednej strony znajdujemy tam przykazania, które dotyczą (podobnie jak w przypadku rozwoju neo-endogennego, choć sformułowane w nieco odmiennym języku) rozmaitych elementów mechanizmu rozwojowego, takich jak: reguły nowej (partycypacyjnej) demokracji, reguły pomocniczości, przestrzegania praw człowieka oraz zasady ostrożności (antycypowania możliwych negatywnych skutków wdrażanych projektów rozwojowych). Z drugiej jednak strony koncepcja rozwoju zrównoważonego zawiera pewne wartości, które w ramach owego mechanizmu muszą być realizowane.

55 T. Adamski, K. Gorlach, Koncepcja rozwoju neo-endogennego, czyli renesans znaczenia wiedzy lokalnej, [w:] Socjologia jako służba społeczna. Pamięci Władysława Kwaśniewicza, pod red. K. Gorlacha, M. Niezgody, Z. Seręgi, Wydawnictwo Uniwersytetu Jagiellońskiego, Kraków 2007, s. 137-150. 
Są to przykazania dotyczące: zachowania ekologicznej równowagi, wspólnego dziedzictwa, zróżnicowania, zatrudnienia (pracy, dobrostanu) oraz równości (sprawiedliwości). W tym więc sensie mechanizm rozwoju, który zapewnić ma realizację wspomnianych wartości zostaje oparty na konieczności postrzegania lokalnej specyfiki, uczestnictwa w procesie formułowania i wdrażania określonych polityk wielu aktorów, wzajemnej ich współpracy oraz wsparcia i asekuracji. Czynnik lokalny jawi się zatem w tym kontekście - naszym zdaniem - nie jako receptor „globalnych” (czy pozalokalnych) projektów, ale jako pełnoprawny uczestnik procesu współrządzenia. Zatem gra o zmiany na poziomie lokalnym toczy się przede wszystkim na poziomie globalnym, ale z pełnoprawnym udziałem przedstawicieli tego pierwszego.

Obydwa zaprezentowane mechanizmy rozwojowe stoją - $\mathrm{w}$ naszym rozumieniu - w sprzeczności z rozpowszechnionym szeroko stwierdzeniem „myśl globalnie, działaj lokalnie”. Zarówno bowiem idea rozwoju neoendogennego, stawiająca na wykorzystanie zasobów lokalnych przy współudziale i w ramach współpracy z aktorami pozalokalnymi, jak i idea rozwoju zrównoważonego kładącego nacisk na zachowanie specyfiki tego co lokalne w procesie szerokiej partycypacji różnych aktorów realizujących zasady pomocniczości i wzajemnej asekuracji w procesie antycypacji możliwych negatywnych zjawisk, świadczą na rzecz tezy o potrzebie myślenia zorientowanego na lokalność, ale wspartego działaniem uwzględniającym (co jest warunkiem sukcesu) to, co globalne (pozalokalne). Najwyższa zatem - naszym zdaniem - pora, aby hasło „myśl lokalnie, działaj globalnie” wprowadzić do naszego dyskursu na temat procesów rozwojowych we współczesnym, zglobalizowanym społeczeństwie.

\section{BIBLIOGRAFIA}

- Adamski T., Gorlach K., Koncepcja rozwoju neo-endogennego, czyli renesans znaczenia wiedzy lokalnej, [w:] Socjologia jako służba społeczna. Pamięci Władysława Kwaśniewi$c z a$, pod red. K. Gorlacha, M. Niezgody, Z. Seręgi, Wydawnictwo Uniwersytetu Jagiellońskiego, Kraków 2007.

- Adamski T., Gorlach K., One tradition many recipies: social networks and food production - the oscypek cheese case, [w:] Naming Food After Places: Food Relocation and Knowledge Dynamics in Rural Development, pod red. M. Fonte, A.G. Papadopoulos, Ashgate, Aldershot 2010. 
- Alternatives to Economic Globalization. A Better World is Possible, pod red. J. Cavanagh, J. Mander, Berrett-Koehler Publishers, San Francisco 2004, s. 77-104 (wydanie drugie, poszerzone).

- Bauman Z., Glokalizacja, czyli komu globalizacja a komu lokalizacja, „Studia Socjologiczne" 1997, z. 3.

- Beck U., Władza i przeciwwładza w epoce globalnej. Nowa ekonomia polityki światowej, Wydawnictwo Naukowe SCHOLAR, Warszawa 2005.

- Berger P., Luckman T., Społeczne tworzenie rzeczywistości, Wydawnictwo Naukowe PWN, Warszawa 2010.

- Castells M., Społeczeństwo sieci, tłum. M. Marody i in., Wydawnictwo Naukowe PWN, Warszawa 2007.

- Elliot J. A., An Introduction to Sustainable Development, Routledge, London-New York 2013.

- Emotion, Place and Culture, pod red. M. Smith, J. Davidson, L. Cameron, L. Boni, Ashgate, Farnham-Burlington 2009.

- Etzioni A., Next: The Road to the Good Society, Basic Books, New York 2001.

- Giddens A., Nowoczesność i tożsamość. „Ja” i społeczeństwo w epoce późnej nowoczesności, tłum. A. Szulżyńska, PWN, Warszawa 2001.

- Gorlach K., Socjologia obszarów wiejskich. Problemy i perspektywy, Wydawnictwo Naukowe SCHOLAR, Warszawa 2004.

- Gorlach K., Socjologia polska wobec kwestii chłopskiej, Universitas, Kraków 1990.

- Gorlach K., W poszukiwaniu równowagi. Polskie rodzinne gospodarstwa rolne w Unii Europejskiej, Wydawnictwo Uniwersytetu Jagiellońskiego, Kraków 2009.

- Gorlach K., Klekotko M., Nowak P., Rozwój społeczny - rozwój zrównoważony - postęp: przyczynek do rozwoju obszarów wiejskich, tekst niepublikowany, Kraków 2013.

- Khondker H. H., Glocalization as globalization: evolution of a sociological concept, "Bangladesh e-Journal of Sociology" 2004, z. 1 (2).

- Klekotko M., Rozwój po ślq̨sku. Procesy kapitalizacji kultury w śląskiej społeczności górniczej, Wydawnictwo Uniwersytetu Jagiellońskiego, Kraków 2012.

- Klekotko M., Gorlach K., Miejsce, lokalność, globalizacja: Przyczynek do problematyki socjologii wsi (i nie tylko) w społeczeństwie ponowoczesnym, [w:] Obszary wiejskie w Polsce: różnorodność i procesy różnicowania, pod. red. Hanny Podedwornej i Andrzeja Pilichowskiego, Wydawnictwo IFiS PAN, Warszawa 2011.

- Komendera A., U podstaw zbiorowości lokalnych, [w:] Zbiorowości terytorialne i więzi społeczne: studia i szkice socjologiczne dedykowane profesorowo Wacławowi Piotrowskiemu w siedemdziesiąta rocznice urodzin, pod red. P. Starosty, Wydawnictwo Uniwersytetu Łódzkiego, Łódź 1995.

- Krzysztofek K., Szczepański M. S., Zrozumieć rozwój. Od społeczeństw tradycyjnych do informacyjnych, Wydawnictwo Uniwersytetu Śląskiego, Katowice 2002. 
- Lubaś M., Przestrzenne skale odtwarzanie miejsca. Analiza społecznej organizacji przestrzeni Wnukowski zachodniej Macedonii, [w:] Społeczne tworzenie miejsc. Globalizacja, etniczność, władza, pod red. A. Bukowskiego, M. Lubasia, J. Nowaka, Wydawnictwo Uniwersytetu Jagiellońskiego, Kraków 2010.

- McMichael P., Development and Social Change A Global Perspective, Pine Forge Press, Thousand Oaks-London-New Delhi 2004 (wydanie 3).

- Nigro S., Glocalization. Research Study and Policy Recommendations, CEFRE \& Glocal Forum, Rome 2003.

- Pakulski J., Postmoderm social theory, [w:] New Blackwell Companion to Social Theory, pod red. B. S. Turner, Wiley-Blackwell, Malden-Oxford-Chichester 2009.

- Perkins H. C., Commodification: re-resourcing rural areas, [w:] Handbook of Rural Studies, pod red. P. Cloke, T. Marsden, P. H. Mooney, Sage Publications, London-Thousand Oaks -New Delhi 2006.

- Ray C., Neo-endogenius rural development in the EU, [w:] Handbook of Rural Studies, pod red. P. Cloke, T. Marsden, P. H. Mooney, Sage Publications, London-Thousand Oaks-New Delhi 2006.

- Robertson R., Globalization: Social Theory and Global Culture, Sage Publications, London -Thousand Oaks-New Delhi 1992.

- Robertson R., Glocalization: Time-space and homogenaty-heterogenity, [w:] Global Modernities, pod. red. M. Featherstone, S. Lash, R. Robertson, Sage, London 1995.

- Rubin H. J., Rubin I., Community Organizing and Development, Allyn and Bacon, Boston 2001.

- Sennett R., The Fall of Public Man, W.W.Norton \& Company, New York 1992.

- Shucksmith M., Disintegrated rural development? Neoendogenous rural development, planning and place shaping in diffused power contexts, "Sociologia Ruralis" 2010, z. 1 (50).

- Starosta P., Poza metropoliq. Wiejskie i małomiasteczkowe społeczności lokalne a wzory porzq̨dku makrospołecznego, Wydawnictwo Uniwersytetu Łódzkiego, Łódź 1995.

- Starosta P., Globalizacja i nowy komunitaryzm, [w:] Niepokojąca współczesność, pod. red. A Miszalskiej i K. Kowalewicza, Wydawnictwo Uniwersytetu Łódzkiego, Łódź 2001.

- Sztompka P., Współczesna socjologia wśród innych nauk społecznych: burzenie murów i przekraczanie granic, [w:] Władza, naród, tożsamość. Studia dedykowane Profesorowi Hieronimowi Kubiakowi, pod. red. K. Gorlacha, M. Niezgody, Z. Seręgi, Wydawnictwo Uniwersytetu Jagiellońskiego, Kraków 2004.

- Sztompka P., Socjologia zmian społecznych, Wydawnictwo ZNAK, Kraków 2005.

- Sztompka P., Socjologia. Analiza społeczeństwa, wydanie drugie, Wydawnictwo ZNAK, Kraków 2012.

- Tam H., Communitarianism. A New Agenda for Politics and Citizenship, MacMillan Press, London 1998.

- Turner J. H., Stets J. E., Socjologia emocji, Wydawnictwo Naukowe PWN, Warszawa 2009. 
- Vanclay F., Place matters, [w:] Making Sense of Place. Exploring Concepts and Expressions of Place through Different Senses and Lenses, pod red. F. Vanclay, M. Higgins, A. Blackshaw, National Museum of Australia, Canberra 2008.

- Wnuk-Lipiński E., Świat międzyepoki. Globalizacja, demokracja, państwo narodowe, Wydawnictwo ZNAK-ISP PAN, Kraków 2004.

- Woods M., Political articulation: the modalities of new critical politics of rural citizenship, [w:] Handbook of Rural Studies, pod red. P. Cloke, T. Marsden, P. H. Mooney, Sage Publications, London-Thousand Oaks-New Delhi 2006.

- Wyborg A., Place, nature and migration: student attachment to their home places, "Sociologia Ruralis" 2004, z. 4.

- www2.warwick.ac.uk/knowledge/business/thinklocal/ (dostęp: 26.05.2013).

\section{Think LoCALLY, ACT GLOBALLY: \\ ON The Human DeVelopment Under Globalization}

The authors argue that the statement firstly used by ecologists and economists does not reflect the nature of balanced relations between the local and the global in contemporary society. It rather reflects the domination of the global over the local. In order to formulate the contradicting argument one has to start with redefinition of locality. Locality has to be conceptualized not as a traditional community but rather as a place and/or new local/glocal community. The changes in glocal community have been connected with two types of development mechanisms, namely: the neo-endogenous and sustainable ones. Both have been focused on the cooperation between local and extra-local actors. Therefore they show to change somehow society we have to think in a perspective of particular localities and later act global in order to form a network of governance to elaborate and implement particular developmental strategies.

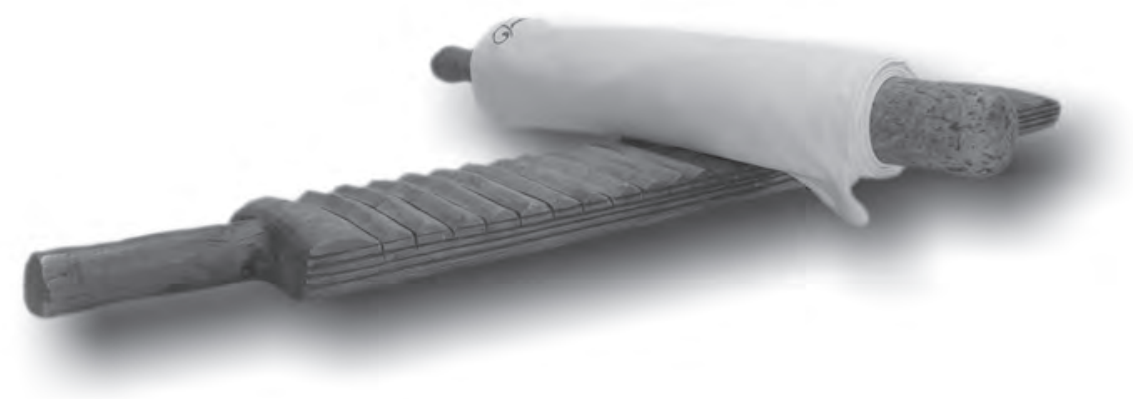

